nych, skrybów i pisarzy. Na wydziale prawa studiowali przyszli politycy, męīowie stanu, twórcy aktów prawnych i zasad postẹpowania w stosunkach miedzynarodowych. Shuchacze teologil skupiali swą uwage nie tylko na zawiłościach doktrynalnych, ale poszukiwali dróg praktyconej pobożności i reformy rozdartego przez schizme Kościoła. Whączało to uniwersytet krakowski w żwy na europejskich uniwersytetach nurt koncyliaryzmu.

Z uniwersytetem związali się wspomniani już Stanisław ze Skalbmierza, Pawel Whodkowic, a takcie Jakub z Paradyża, Jan Szczekna, Jan Isner, Mikołaj z Gorzowa, Barttomiej z Jasła, Mikołaj z Pyzdr, Mikołaj Wigand. Otwieraja oni zaledwie długi poczet wybitnych profesorów uniwersytetu, który stał sį „nank przemożnych perła". Spelnily się zatem slowa Jana Długosza: zacrąl zaś odtąd Uniwersytet Krakowski, zalożony pierwotnic przez króla polskiego Wladysława i królowa Jadwige, a zatwierdzony przez papieza Jana XXII, a potem przez papieia Mancina V, rozkwitać i bujnie się rozwijać w nóżnych gałepảach wiedzy i wydawać spośród Polaków męzów uczonych, pracowitych i roztropnych i rozsławiać szeroko imię Królestwa Polskiego".

\title{
Nota bibliograficana
}

Utworzenie pierwszego na ziemiach polskich uniwersytetu opisane zostalo w licanych opracowaniach, wśród których na pierwszym miejscu wymienić nalęy Dzieje Uniwersytetu Jagiellońskiege w latach 1364-1764, t 1-2, Kraków 1964, praca omawia dokonania wczéniej sxej histnriografii. Driałania Kazimierza Wielkiego przedstawili J. Wyrozunski, Kazimierz Welki, Wrochaw 1986; F. Kiryk, Whelki król i jego nastepca, Kraków 1992, HL Baryc, Abna Mater Jagellonica Studia i szkice z przeszlosci Uniwersytetu Krakowskiego, Kraków 1958. Działania zmierzające do reformy i realtywowania uczelni omówione zostały w pracach K. Özóga, Intelektualiści w shuzbie Królestwa Polskiego w latach 1306-1382, Kraków 1995, M. Kowalczyl, Odnowienie Uniwersytetu Krakowskiego w swietle mów Bartlomieja z Jasla, „Malopolskie Studia Historycrne” 6 (1964), s. 23-42 Z Kozlowska-Budkowa przedstawila wydarzenia z lipca 1400 r. w pracy: Odnowienie Jagielloŕskie Uniwersytetu Krakowakiego, w: Dzieje Uniwersytetu Jagiellovisliego $\rightarrow$ t 1, s. 44 i nn. Role krölowej Jadwigi w odnowieniu uniwersytetu w Krakowie opisały. A. Strzelecka, 0 knolowej Jadwidze Studia i przyczynki, Lwów 1933, A. Klubówna, Królowa Jadwiga. Opowiéśc o czasach i budziach, Warzzawa 1986, natomiast dziatania króla Whadysława Jagielły J. Krzyżaniakowa, J. Ochmaniski, Whadyslaw II Jagiello, Wrockaw 1990. O wybitnych profesorach krakowskich z XV w. pisał L. Fhrlich, Pawel Modkowic i Stanislaw ze Skarbimierza, Warszawa 1954. Zob. tez inne prace tego autora.

\section{Towarzystwo \$w. Wincentego à Paulo. Sto piećdziesiąta rocznica zalożenia pierwszej Konferencji messkiej w Poznaniu}

Wiek XIX i początek wieku XX w zaborze pruskim zapisał się jako okres wzmożonej i wszechstronnej działalności dobroczynnej. Prace filantropijna prowadziły zakony meskie, jeniskie, ksieja diecezjalni, a talcze - co należy szcrególnie podkreślić - na zoaczną skalę stowarzyszenia 
katolików świeckich ${ }^{1}$. We wspieraniu ubogich kierowano się przesłankami religijnymi, gdyż „Wszyscy wierni [...] powinni ją wykonywać i ze względu miłości bliźniego, nakazującej przychodzić mu z pomocą i ze względu na religijne pojęcie własności². Stąd też dobroczynność pojmowano jako cnotę chrześcijaŕską, dzięki której wierzący dobrowolnie poświęcali część swojej wlasności na wsparcie bliźnich będących w niedostatku, bowiem pomoc taka zawsze „musi wychodzić z miłości Boga i z miłości bliźnich dla Boga"3. Był to akt miłosierdzia chrześcijańskiego, które Kościół głosił już od samych początków w swoim nauczaniu^. W świadczeniu miłosierdzia katolicy inspirowani byli m.in. wskazaniami papieży kierowanymi do nich w listach i encyklikach. Szczególne zainteresowanie Kościola problemami społecznymi daje sį̨ zauważyć w XIX wieku. Wynikało ono z pogarszającej się sytuacji materialnej licznych grup i warstw społecznych żyjących w niedostatku czy wręcz biedzie na skutek procesów urbanizacyjnych i industrializacyjnych. Aby tym negatywnym zjawiskom i procesom społecznym chociaż częściowo zaradzić i ulżyć żyjącym w ubóstwie, katolicy inspirowani encyklikami papieży organizują się w stowarzyszenia dobroczynne. Na ziemiach polskich pod zaborem pruskim o uczestnictwie Polaków w stowarzyszeniach dobroczynnych i zaangażowaniu w pracy filantropijnej decydował jeszcze jeden, nie mniej ważny, czynnik, a mianowicie uczestnictwo takie i działalność traktowano jako obowiązek patriotyczny i posłannictwo narodowes.

Praca charytatywna stowarzyszeń katolickich kompensowała niedostatki instytucjonalnej opieki w drugiej polowie XIX i początkach XX wieku. Potrzeby w tym zakresie były znaczne, spowodowane migracją ludności do miast, bezrobociem, trudną sytuacją materialną rodzin. Brak zabezpieczenia bytu materialnego, niski poziom higieny, choroby, brak właściwie zorganizowanej opieki państwowej to wszystko wpływało również na stan moralny części społeczeństwa w Poznańskiem. Stąd też Witold Szulc konstatuje, iż „pewnej pomocy dla najuboższej części społeczeństwa udzielały organizacje filantropijne $i$ instytucje spoleczne". Jedna $z$ takich organizacji filantropijnych było Towarzystwo $\mathbf{S}$. Wincentego à Paulo.

Towarzystwo Św. Wincentego à Paulo początkiem swym sięga pierwszej polowy XIX wieku. Wówczas to w Paryżu w 1833 roku młodzież akademicka zaczęła się spotykać w kolach samokształceniowych na tzw. Konferencjach historycznych, gdzie dyskutowano tematy $\mathrm{z}$ historii, literatury, filozofii, społeczne. Takie dyskusje nie zaspokajały jednak zainteresowań i potrzeb pewnej części młodzieży w zakresie uczestniczenia w życiu społecznym. Grupa młodych wierzących ludzi pragnę̧ła czegoś wiẹcej, niż tylko dyskusji. Chciała realizowania zasady wiary w swoim codziennym życiu, próbując w ten sposób przekonać niewierzących kolegów o słuszności wybranej przez siebie drogi życiowej wyznaczonej wiarą katolicką. Również nowe ateistyczne prądy filozoficzne oraz ideowe $w$ porewolucyjnej zachodniej Europie przysparzały przeciwnikom

'C. Strzeszewski, M. Banaszak, Chrzescijanska mysl i dzialalnosć spoleczna w zaborze pruskim w latach $1865-1918$, w: Historia katolicyzmu spolecznego w Polsce 1832-1939, kom. red. C. Strzeszewski (przew.), R. Bender, K. Turowski, Warszawa 1981, s. 89-116; Z. Zieliński, Kościdl katolicki w Wielkim Ksiestwie Poznańskim w latach 1848-1865, Lublin 1973, s. 259-262; J. Nowacki, Dzieje Archidiecezji Poznariskiej, Poznań 1964, t. 2, s. 737-753; S. Karwowski, Historia Wielkiego Księstwa Poznariskiego, Poznań 1918, t. 1, s. 546-549.

${ }_{2}^{2}$ Encyklopedia kościelna podhu teologicznej encyklopedii Wetzera $i$ Weltego z licznemi jej dopehieniami przy wspolpracownictwie kilkunastu duchownych $i$ swieckich osób, wydana przez X. Michała Nowodworskiego, Warszawa 1874 , t. 4, s. 245.

3 Ibidem, s. 246.

4 Zob.: J.S. Pelczar, Zarys dziejów milosierdzia w Kościele katolickim, Kraków 1916; T. Glemma, Z dziejów milosierdzia chrześcijaŕskiego w Polsce, Kraków 1947.

${ }^{5}$ Zob. min.: L. Trzeciakowski, Aktywnosé polityczna poznaniaków, w: Dzieje Poznania, pod red. J. Topolskiego i L. Trzeciakowskiego, Warszawa - Poznań 1994, t. 2, s. 353-372; C. Strzeszewski, M. Banaszek, Chrześcijariska mysl.., op. cit., s. 63-112.

6 W. Szulc, Rynek pracy oraz polożenie ekonomiczne klasy robotniczej, w: Dzieje Wielkopolski, pod red. W. Jakóbczyka, Poznań 1973, t. 2, s. 444. 
Kościoła katolickiego argumentów do dyskryminacji katolików w życiu publicznym. Młodzi ludzie z niepokojem obserwowali ataki na Kościół katolicki i katolicyzm, dostrzegając jednocześnie coraz trudniejsze warunki życia znacznej części społeczeństwa powiększajq̨ce zakres ubóstwa. To sprawilo, że chcąc realizować społeczną naukę Kościoła w swoim codziennym życiu, do pracy kół włączono min. odwiedzanie ubogich w ich mieszkaniach, aby przynieść im wsparcie materialne i duchowe. Stąd działalność ta stała się odtąd jednym z głównych i zasadniczych celów organizowania się tej części młodzieży akademickiej.

Konferencje historyczne przerodziły się w Konferencje miłosierdzia?, a za patrona obrano Św. Wincentego à Paulo ${ }^{8}$, od którego wzięły one nazwę Konferencji $\mathbf{S} w$. Wincentego à Paulo, a sama organizacja Towarzystwa Św. Wincentego à Paulo. Jednym z inicjatorów i założycieli pierwszej Konferencji był student prawa odznaczający się szczególną żarliwością i aktywnością w dziele miłosierdzia, a późniejszy wykładowca Sorbony Fryderyk Ozanam?.

Powstające Konferencje ożywione myślą i wzorem Św. Wincentego kompensowały destrukcyjne efekty procesów sekularyzacyjnych i były wyrazem odpowiedzialności i dojrzałości chrześcijańskiej katolików świeckich ${ }^{10}$. Towarzystwo rozwijało się dynamicznie. Przybywało nowych członków, rosła liczba Konferencji i w krótkim czasie idea wincentyńska realizowana w myśl założeń i koncepcji Fryderyka Ozanama rozprzestrzeniła się poza granice Francji.

Na ziemiach polskich pierwszą Konferencje powołano w Wielkim Księstwie Poznańskim w 1850 roku: „d. 17 Lutego r. 1850, w pierwszą Niedziele Wielkiego Postu dwunastu chętnych osób... [spotkało się - J. S.] na Garbarach, celem zawzięcia Towarzystwa Sw. Wincentego w Poznaniu. Tam zawiązano pierwszą na ziemi polskiej konferencya....".

Inicjatorem utworzenia Konferencji i pierwszym jej prezesem był Edward hrabia Lubieński ${ }^{12}$. W gronie pierwszych członków i współzałożycieli „spotkamy ludzi znanych i zasłużonych

7 Towarzystwo sw. Wincentego à Paulo jego zalożenie, rozwój i dzialalność, Kraków 1933, s. 4-9.

- Wincenty a Paulo (1576-1660) byl zalożycielem Zgromadzenia Misjonarzy (Lazarystów) i Sióstr Miłosierdzia (Szarytki), a także świeckich Bractw Milosierdzia we Francji. Zgromadzenia zakonne i Bractwa w poshudze najbiedniejszym mialy się kierować wg wskazań św. Wincentego zasada iż ludzi będących w niedostatku można podzielić na cztery kategorie: 1 - którzy pracować nie mogą z powodu wieku, kalectwa, choroby i im należy dać wszystko, czego do życia potrzebują 2 - którzy nie moga zarobić tego, co im do życia potrzebne i tu należy uzupelnić to, czego im brakuje. Tak więc pierwszych należy utrzymywać, a drugich podtrzymywá́; 3 - którzy nie mogą znaleźć pracy i im należy pomóc w znalezieniu pracy; 4 - którzy nie umieją pracować i tych należy pracy wyuczyć. Miłosierdzie chrześcijańskie w koncepcji św. Wincentego a Paulo to nie tylko pomoc materialoa, ale przede wszystkim przygotowanie do pracy i życia, polegające „na tym, że naucza sie ubogich prawd wiary i zasad życia chrześcijańskiego". Zob. Towarzystwo Sw. Wincentego d Paulo, jego zalożenie..., s. 3-4; J.M. Roman, Swiety Wincenty d Paula biografia, Kraków 1990, s. 157, 161 - 164; Encyklopedia kościelna podhig teologicznej encyklopedii Wetzera.., s. 411-419; G. Hunermann, Ojciec ubogich, Swiety Wincenty d Paulo, Kraków 1989.

Fryderyk Ozanam (1813-1853) - doktor prawa i profesor prawa handlowego w Lyome. Zamlkowanie jednak przejawiał do nauk historycznych, literackich i filozoficznych. Znawca języków starożytnych, włoskiego, hiszpańskiego, angielskiego i niemieckiego. Broni prace konkursową na stopień doktora nauk wyzwolonych i zostaje profesorem literatury na Sorbonie w Paryżu, poświęcając się badaniom nad XIII wiekiem, jego cywilizacją i literaturą. Beatyrikowany przez Papieża Jana Pawla II 22 sierpnia 1997 r. Zob. Przemówienie prof. dr. Stanislawa Karwowskiego w stuletniq̨ rocznice urodzin Fryderyka Ozanama, Poznań (b.r.n.), s. 2-3; Towarzystwo $S_{w}$. Wincentego d Paulo, jego zalożenie...

$10 \mathrm{~J}$. Myszor, Stosunek duchowienstwa parafialnego do idei zwiqzkowej w Kościele na przykladzie powstanio i rozwoju Konferencji $S_{w}$. Wincentego d Paulo w diecezji wroclawskiej (1848-1911), w: Duchowienstwo slaskie wobec przemian spoleczno-kulturalnych w XIX $i$ pierwszej polowie $X X$ wieku, Warszawa 1995, s. $35-52$.

"Towarzystwo Świętego Wincentego, przedruk z "Tygodnika Katolickiego", Grodzisk 1863, s. 29.

12 Edward hrabia Lubieński (1819-1867). Urodzil sic̨ w Warszawie, kształcił w Petersburgu i Berlinie, gdzie założyl wśród mlodzieży Towarzystwo Katolickie. Po poślubieniu Zofii Giżyckiej zamieszkał w Poznaniu (w 1844 roku). Tu zaprzyjaźnił się z Adamem Luszczewskim, który budził ducha mikosierdzia w wyższych sferach spoleczeństwa Wielkopolski. W domu państwa Luszczewskich Lubieński utwierdzał się w wierze katolickiej i zasadach konserwatywnych, a także w potrzebie pracy dobroczynnej. Zalożył pierwsza katolicka ksieggarnię i pierwsza Konferencję Sw. Wincentego á Paulo. W 1852 r. opuścił na stałe Poznań i osiadł w Rzymie, oddając sie tu pracy literackiej i publicystycznej. Pod koniec życia przeniósł się do Galicji. Zmarł w Wiedniu. S. Karwowski, Historia Wielkiego Ksiestwa..., t. 1, s. $549-550$. 
Kościołowi i Ojczyźnie..." ${ }^{13}$. Wśród nich znaleźli się tak wybitni Wielkopolanie, jak Aleksy Prusinowski, Wojciech Morawski, Michał Mycielski, Jan Koźmian, Stanisław Koźmian, Jan Janiszewski, Dezydery Chłapowski, Edmund Bojanowski i Tytus Daszkiewicz.

Towarzystwo Sw. Wincentego ả Paulo już od samego początku rozwija się w Poznańskiem niezwykle dynamicznie. Powstają coraz to nowe konferencje. W 1852 zaistniała konieczność utworzenia Rady Miejscowej, a jej pierwszym prezesem został Michał Mycielski. Wielkopolanie chętnie garnęli się do pracy charytatywnej. Zaowocowało to istnieniem po pierwszych pięciu latach około 40 konferencji. Najświetniejszy okres rozwoju nastąpił w latach 1862 - 1868, kiedy to prezesem Rady Wyższej był ks. Antoni Brzeziński, profesor poznańskiego seminarium duchownego. Pracowało wówczas 65 konferencji, które liczyły 2050 członków ${ }^{14}$. Zadania swoje realizowano poprzez odwiedzanie rodzin, opiekę nad sierotami, dziećmi zaniedbanymi, pomoc dla ochronek, prowadzenie szkółek niedzielnych dla uczniów rzemieślniczych, opiekę nad żyjącymi bez sakramentalnych związków małżeńskich, wyszukiwanie pracy dla ubogich i pośredniczenie w staraniach o pracę, prowadzenie kas oszczędności na komome dla biednych, odwiedzanie chorych w szpitalach, opiekę nad umierającymi, zwolnionymi z więzień, pomoc biednym w pogrzebach, wpływanie na zawieranie zgody i unikanie procesów, prowadzenie pracowni dla ubogich ${ }^{15}$. Były to na ogół stałe formy pracy wynikające z sytuacji oraz potrzeb materialnych i duchowych Polaków żyjących w zaborze pruskim.

W tym dziele inspiracji, zachęt i znaczącego poparcia udzielał ks. abp Leon Przyłuski (1789-1865). Okólnikiem w kwietniu 1855 roku zwrócił się do duchowieństwa, aby zakładało w swoich parafiach konferencje. Żądał od księży sprawozdań z dzialalności charytatywnej. Sam dawal osobisty przykład będąc członkiem Towarzystwa $\$$ w. Wincentego, z własnych funduszy utrzymywał ochronkę w Gnieźnie ${ }^{16}$.

We wspomnianym okólniku nie tylko zachęcał, ale i nakazywał duchowieństwu zakkładanie bibliotek parafialnych. Czytelnictwo już od samego początku należało do bardzo ważnych zadań i wobec tego przywiązywano do tej formy pracy duże znaczenie, gdyż już w 1853 roku „rozpoczęło Towarzystwo dzieło rozrastające się odtąd bardzo skutecznie, a obiecujące [...] dobrze prowadzone [...] w przyszlości jeszcze większe korzyści, to jest czytelnie pobożne"17. Już w pierwszym roku istnienia czytelnia rozdała pomiędzy ubogich 580 czasopism.

Okólnik i duże zainteresowanie czytelnictwem skłoniło Radę Wyższą do powołania specjalnej komisji do zakładania bibliotek parafialnych. Na czele komisji stanął księgarz Tytus Daszkiewicz, który 29 stycznia 1862 roku w liście skierowanym do abpa Leona Przyłuskiego mógł napisać, że „nasze Konferencje [...] posiadają mniej więcej liczne zapasy książek moralnych, które nie tylko przez współbraci naszych czytane bywają $z$ wielkim zajęciem $\mathrm{i}$ upragnieniem, ale nawet przechodząc z ręki do ręki są czytane i poszukiwane od nieczłonków pozaparafialnych" ${ }^{18}$. Potwierdzają to sprawozdania Komisji, gdzie można przeczytać, iż w roku 1866 prowadzono już 43 biblioteki. Korzystało z tych bibliotek 2097 czytelników, którzy przeczytali 10690 książek $^{19}$. W tym obrazie

${ }^{13}$ Towarzystwo Św. Wincentego d Paulo, jego zalożenie..., s. 11-12.

14 J. Myszor, Konferencje $\$ w$. Wincentego d Paulo - charytatywne stowarzyszenie katolików swieckich w Polsce; powstanie, rozwój i likwidacja (1850-1950), w: Caritas - zawód czy powolanie? Material sesji naukowej zorganizowanej przez Caritas Polska i Studium Caritas Wydzialu Kościelnych Nauk Historycznych $i$ Spolecznych ATK w Warszawie w dniach 8-9.X.1996 r. Red. naukowa ks. prof. dr hab. H. Skowroński, ks. dr J. Koral, Warszawa 1996, 8. 61; Towarzystwo św. Wincentego d Paulo jego zalożenie..., s. 12

15 A. Loster, Wczoraj, dzis $i$ jutro Konferencji wielkopolskich, "Ruch Charytatywny" R. 10: 1931, s. 212 -213; Towarzystwo Sw. Wincentego, przedruk... op. cit, s. 31-34; 53 i n.

16 C. Strzeszewski, M. Banaszak, Chrześcijariska myśl.., s. 113.

17 Towarzystwo Sw. Wincentego, Przedruk..., s. 32.

18 Archiwum Archidiecezjalne w Poznaniu, rkps. sygn. OA VI 62. Sq to akta dotyczace czytelni parafialnych zakładanych przez Towarzystwo sw. Wincentego a Paulo w latach 1862-1868.

" Ibidem; Zob. też: W. Jakóbczyk, Studia nad dziejami Wielkopolski w XIX w. Dzieje pracy organicznej, Poznań 1959, t. 2, s. 37-39; B. Kosmanowa, Biblioteki polskie w Wielkim Księstwie Poznańskim, Poznań 1982 s. 83-86; J. Wróblewski, Polskie biblioteki ludowe w zaborze pruskim 1843-1939, Olsztyn 1975, s. 37-40, W. Molik, Warunki rozwoju polskiego rynku czytelniczego w Wielkim Ksiestwie Poznariskim (1815-1914), w: Pomorze - Polska - Europa, Studia $i$ materialy z dziejów XIX i XX wieku, Toruń 1995, s. 43-56. 
czytelnictwa należy jeszcze uwzględnić przeczytane książki „przechodzące z ręki do ręki” - jak pisał do abpa Leona Przyłuskiego - Tytus Daszkiewicz.

Od 1859 roku Towarzystwo posiadało swoje wydawnictwo. Były to „Roczniki Towarzystwa Św. Wincentego à Paulo". Stanowiły one płaszczyznę wymiany koncepcji, doświadczeń w pracy charytatywnej katolików świeckich.

W pracy Towarzystwa uczestniczyło wielu wybitnych Wielkopolan tego okresu. Wśród nich na szczególną uwagę zasługują Edmund Bojanowski i Celestyna Działyńska, którzy poświęcili się opiece i wychowaniu dziecka wiejskiego, a także nieco później Heliodor Święcicki. Działalność Bojanowskiego jest już dosyć dobrze poznana dzięki bogatej literaturze ${ }^{20}$. Natomiast zasługi Celestyny Działyńskiej - nie mniej znaczące - nie są niestety jeszcze tak opisane, jakby na to zasługiwały. Celestyna z Zamoyskich hrabina Działyńska (1804-1883) ma wyjątkowe zasługi w dziele miłosierdzia chrześcijańskiego inspirowanego ideą wincentyńską. W działalności charytatywnej i oświatowej była niezmordowana, wyręczając w tym swojego męża. Brała udział w pracach różnych towarzystw dobroczynnych. W działalności dobroczynnej Działyńska postanowiła oprzeć się na żeńskim zgromadzeniu zakonnym, które sprostałoby takim zadaniom i wybór jej padł na Zgromadzenie Sióstr Miłosierdzia św. Wincentego à Paulo, popularnie zwanych szarytkami. Dlatego też przekształca w 1853 roku Towarzystwo Dobroczynności Dam Polskich w Towarzystwo Pań Miłosierdzia św. Wincentego à Paulo. Będąc prezeską Towarzystwa Pań Miłosierdzia Działyńska prowadziła akcje oświatowe, organizowała w parafiach biblioteczki (w Poznaniu i okolicy), zakładała szkółki, ochronki i szpitale. Pisała dla dzieci z ochron wiersze, powiastki, pieśni, a dla nauczycielek pracujących $w$ tychże ochronach instrukcje i pewne zasady metodyczne pracy $\mathrm{z}$ dziećmi.

Ważną postacią nadającą kierunek pracom Towarzystwa św. Wincentego à Paulo był też Heliodor Święcicki (1854-1923) - profesor medycyny, pierwszy rektor Uniwersytetu Poznańskiego (1919-1923), a zarazem wielki społecznik. Był m.in. przez blisko 20 lat (1895-1914) przewodniczącym Poznańskiego Komitetu Towarzystwa Pomocy Naukowej im. Karola Marcinkowskiego. Kiedy powołano Towarzystwo Społeczno-Higieniczne w Poznaniu (1904), wśród jego pierwszych członków był Heliodor Święcicki. Wtedy to honorowo udzielał świadczeń lekarskich w specjalnej lecznicy dla ubogich. Innym kierunkiem jego działania było Towarzystwo Oświaty Ludowej. Działalność Towarzystwa Święcicki wspierał finansowo. Był - w popularyzowaniu oświaty ludowej - niezwykle aktywny. Niemała rolę odegrał też Święcicki w pracy dobroczynnej w Towarzystwie Św. Wincentego á Paulo. Jego duże moźliwości organizatorskie uwidoczniły się kiedy był prezesem Rady Wyższej w latach $1906-1910$.

W okresie międzywojennym nastąpił dalszy rozwój Towarzystwa i form jego pracy. Generalnej reorganizacji poddano wincentyński ruch kobiecy. W zasadzie ruch wincentyński w swojej klasycznej formie był ruchem wyłącznie męskim. Jednakże w Niemczech i na ziemiach polskich zaboru pruskiego i austriackiego zorganizowały się stowarzyszenia kobiece ${ }^{21}$. Konferencje kobiece wzorowane na statucie konferencji męskich zostały przekształcone w Stowarzyszenia Pań Miłosierdzia i stały się one stowarzyszeniami kościelnymi. W ten sposób sięgnięto bezpośrednio do tradycji stowarzyszeń dobroczynnych zakładanych przez Sw. Wincentego od 1617 roku. Stowarzyszenie Pań Miłosierdzia weszło w skład Akcji Katolickiej. Nawiązano również bardzo bliskie związki z Caritasem, w wyniku czego czasopismo „Przewodnik Miłosierdzia” było miesięcznikiem Związku Towarzystw Dobroczynności „Caritas” i Rad Wyższych Konferencji Św. Wincentego à Paulo.

\footnotetext{
${ }^{20}$ Zob. S. Jankowiak, Edmund Bojanowski 1814 - 1871, Zycie i dzialalnośc, Grabonóg 1995; Z Niedźwiedzka, Edmund Bojanowski prekursor Soboru Watykańskiego II, Wrockaw 1983; A. Szlęgiewicz, Edmund Bojanowski i jego dzielo, Poznań 1966; U. Galas, Edmund Bojanowski (1814-1871), zestawienie bibliograficzne, Leszno 1984 oraz liczne artykuly.

21 J. Myszor, Konferencje sw. Wincentego d Paulo..., s. 65-66.
} 
J. Myszor stwierdza, że w okresie międzywojennym dominowała tendencja ochrony autonomiczności ruchu wincentyńskiego wyrażająca się niechęcią włączania towarzystw w struktury Caritas, z drugiej zaś strony biskupi usiłowali doprowadzić do scentralizowania wszystkich kościelnych stowarzyszeń charytatywnych w jeden Związek Towarzystw Dobroczynnych Caritas wchodzący w skład Akcji Katolickiej ${ }^{22}$. W Polsce, w tym okresie działało - wg sprawozdania z 1930 roku - 370 Stowarzyszeń Pań Miłosierdzia grupujących 36136 członkiń. Najwięcej Stowarzyszeń było w Wielkopolsce i na Pomorzu - około $150^{23}$. Konferencje męskie nie przechodziły takich przekształceń, działając według przyjętych $\mathrm{i}$ utrwalonych zasad współpracując z Caritasem i Akcją Katolicka.

Po drugiej wojnie światowej w 1946 roku w archidiecezji poznańskiej swoją działalność odnowiło 60 Stowarzyszeń Pań Milosierdzia i 8 Konferencji Panów Sw. Wincentego à Paulo. Opiekowaty się one w tym czasie 1500 rodzinami, 100 osobami samotnymi, 470 kalekami i chorymi oraz 300 biednymi $^{24}$. Taka działalność charytatywna po wojnie była bardzo potrzebna. Jednakże polityka nowych władz wobec Kościoła i organizacji charytatywnych zmierzała stopniowo, ale konsekwentnie, do likwidacji dobroczynności prowadzonej przez środowiska wyznaniowe. Stało się to w roku 1950. Udział katolików świeckich w świadczeniu miłosierdzia chrześcijańskiego jednak nie zamart, był nadal realizowany poprzez parafialne grupy istniejące przy kościołach.

Działalność towarzystw charytatywnych oparta na ideach wincentyńskich cechowało dostosowywanie się do coraz to nowych warunków społecznych i potrzeb, jakie przynosil czas. Zawsze jednak w centrum zainteresowania była rodzina, chorzy, więźniowie, umierający i opuszczeni, porzucone samotne dzieci, zagrożona młodzież - zgodnie z zapisami w dokumentach statutowych i idę założyciela i patrona.

\footnotetext{
${ }^{22}$ Ibidem; J. Gaworzeski, Stowarzyszenie Pan Milosierdzia a Akcja Katolicka, „Ruch Charytatywny”, R. 10: 1931, s. $321-322$.

23 J. Myszor, Konferencje...

24 Ibidem, s. 68.
} 